\title{
Ecosystem Service Function and Assessment of the Value of Grape Industry in Soil-Burial Over-Wintering Areas
}

\author{
Zhilei Wang ${ }^{1,+}\left(\mathbb{D}\right.$, , Xiao Cao ${ }^{1,+}$, Liang Zhang ${ }^{1}$, Xing Han ${ }^{1}$, Ying Wang ${ }^{1}$, Hua Wang ${ }^{1,2,3,4, *}$ and Hua Li ${ }^{1,2,3,4, *}$ \\ 1 College of Enology, Northwest A\&F University, Yangling 712100, China; wangzhilei@nwafu.edu.cn (Z.W.); \\ caoxiao@nwafu.edu.cn (X.C.); zhangliang20@nwafu.edu.cn (L.Z.); hanxing@nwafu.edu.cn (X.H.); \\ wangying2018@nwafu.edu.cn (Y.W.) \\ 2 Engineering Research Center for Viti-Viniculture, National Forestry and Grassland Administration, \\ Yangling 712100, China \\ 3 Shaanxi Engineering Research Center for Viti-Viniculture, Yangling 712100, China \\ 4 China Wine Industry Technology Institute, Yinchuan 750021, China \\ * Correspondence: wanghua@nwafu.edu.cn (H.W.); lihuawine@nwafu.edu.cn (H.L.); \\ Tel.: +86-029-87091099 (H.W.); +86-029-87082805 (H.L.) \\ + These authors contribute equally to this work.
}

Citation: Wang, Z.; Cao, X.; Zhang, L.; Han, X.; Wang, Y.; Wang, H.; Li, H Ecosystem Service Function and Assessment of the Value of Grape Industry in Soil-Burial OverWintering Areas. Horticulturae 2021, 7 , 202. https://doi.org/10.3390/ horticulturae7070202

Academic Editors: Massimo Bertamini and Gianluca Allegro

Received: 7 June 2021

Accepted: 17 July 2021

Published: 20 July 2021

Publisher's Note: MDPI stays neutral with regard to jurisdictional claims in published maps and institutional affiliations.

Copyright: () 2021 by the authors Licensee MDPI, Basel, Switzerland. This article is an open access article distributed under the terms and conditions of the Creative Commons Attribution (CC BY) license (https:// creativecommons.org/licenses/by/ $4.0 /)$.

\begin{abstract}
As a representative economic crop with the potential for long-term sustainable development, grapevines (Vitis vinifera L.) bring direct economic benefits to the people, and the indirect ecological benefits produced by grapevines cannot be ignored. This study utilized relevant statistical data from the government sectors and data obtained at vineyards and wineries through interviews and surveys. The value of the ecosystem service of the grape industry in soil-burial over-wintering areas was first evaluated from four first-level indicators types and 10 s-level indicators types, using Hongsibu of the eastern foothill of Helan Mountain, Ningxia, as an example. The results show that the total current benefits of the grape industry ecosystem service function in Hongsibu are $¥ 1067$ million. The direct economic benefits are $¥ 660$ million and indirect ecological benefits are $¥ 407$ million. The value ranking of the first-level function types is as follows: supply services > cultural services $>$ support services $>$ regulatory services. The ranking of the value of second-level function types is as follows: food production $>$ ecological poverty alleviation $>$ biodiversity $>$ carbon fixation and oxygen release $>$ ecotourism $>$ air purification $>$ nutrient accumulation $>$ water conservation and efficiency $>$ water holding $>$ soil conservation. Cultivation measures (such as burial-free cultivation technology, inter-row grass technology, and suspending grape branches after winter pruning technology) increased the value of the service function of the grape ecosystem and explored some potential benefits. The results indicated the necessity of assessing ecosystem service value of the grape industry, which could enable people to realize the direct economic benefits as well as the ecological benefits. Meanwhile, the positive effects of cultivation techniques on the value of ecosystem service function were demonstrated in soil-burial over-wintering areas. This study provides important reference value and comprehensive guidance for the healthy and sustainable development of the grape industry.
\end{abstract}

Keywords: viticulture; soil-burial over-wintering areas; grape industry; ecosystem service function

\section{Introduction}

Statistics released by the OIV (International Organization of Vine and Wine) indicated that the total area of global grape cultivation was 7.4 million ha in 2018 , of which 875,000 ha are cultivated in China [1]. Thus, China has become the world's second largest grapegrowing country. China has a wide range of grape-growing areas. There are grapevines grown in 32 provinces across the country [2]. However, excellent grapevines growing areas are primarily concentrated in arid and semi-arid areas in northern China [3]. These regions have cold winters, strong wind and blowing sand, and low temperatures [4]. If the vines 
are not insulated in time, they will dry in the air and develop freeze injuries, which will affect the growth and yield of the grapevines in the following year [5].

Grapevines are thermophilic plants. Most grapevines cultivated in China are V. vinifera varieties, which require soil-burying to safely over-winter, as the mature shoots of $V$. vinifera can only tolerate a low temperature of about $-15^{\circ} \mathrm{C}$ during winter dormancy [6-8]. Wang et al. analyzed 30 years (1982-2011) of meteorological data from 2294 meteorological stations in China. They selected the soil-burial over-wintering areas using the location that experienced an annual extreme minimum temperature of less than or equal to $-15^{\circ} \mathrm{C}$ more than three times within 30 years $[9,10]$, as shown in Figure 1.

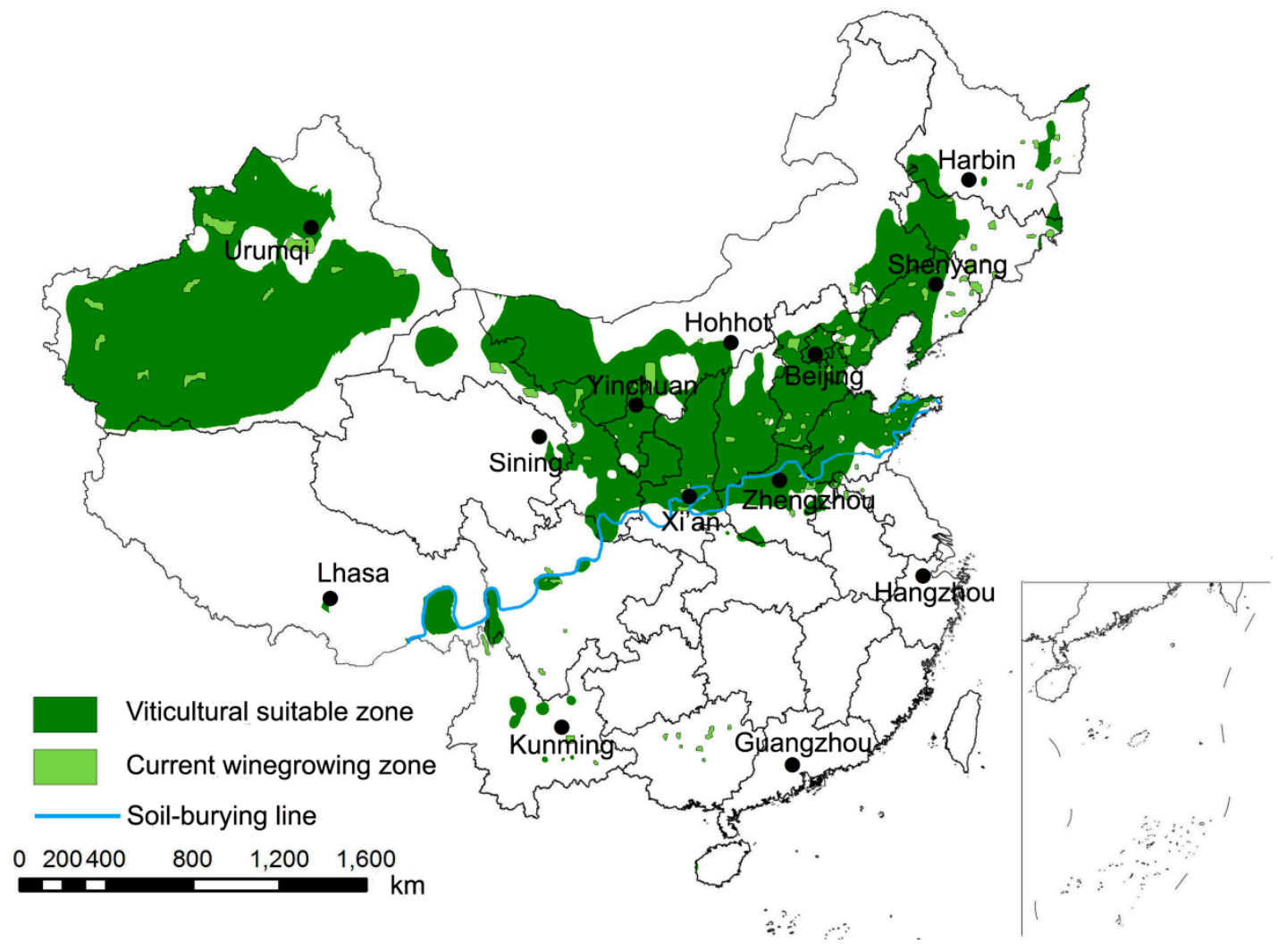

Figure 1. Distribution of suitable viticultural zone and current winegrowing zone in viticultural climatic zoning map of China. Viticultural suitable zone according to the special continental monsoon climate characteristics in China; current winegrowing zone according to the distribution of Chinese wine regions; soil-burying line according to the annual extreme minimum temperature was less than or equal to $-15^{\circ} \mathrm{C}$ for more than three times within 30 years.

Ninety percent of the grapevines in China are located in the soil-burial over-wintering areas [3]. Grapevines are protected from the cold by burying the vines, which damages the soil surface, accelerates wind erosion, increases soil carbon emissions, and affects the grape ecosystem to some extent [3,11]. Liu et al. determined the effect of in-row mulching in the Yinchuan region on the ecological environment of the vineyard [12]. They found that in-row branches and straw mulch can significantly reduce the air temperature and humidity of the canopy of grapevines and soil temperature and increase the number of soil microorganisms. This is consistent with the research of $\mathrm{Xi}$ and others on the cover cropping system of vineyards [13-15]. Wang studied the ability of grapevines to serve as windbreaks in winter in the soil-burial over-wintering areas and found that windbreaks of grapevines branches can change the structure of the wind and sand flow near the surface of the vineyard during the period of soil-burial over-wintering and affect the distribution of sand transport near the surface [16]. The grapevines have blocks and cause the wind and sand to subside, resulting in an average value of total sediment transport within 5 to $150 \mathrm{~cm}$ from the surface to be $39.0 \%$ higher than the control [17]. The study also found that 
branch wind barriers significantly affect the wind erosion of the vineyard. Wind barriers settle sand particles in the wind, and wind erosion primarily results in sedimentation, which reduces the amount of erosion by $75.85 \%$ [17].

As a service crop, grapevines are considered to play a role in soil protection. In addition, the vineyard provides a large number of ecosystem services, such as weed control, pest and disease regulation, water supply, water purification, field trafficability, soil biodiversity, carbon sequestration, alleviating poverty and land degradation [18-21]. Currently, the research on the grape industry in the soil-burial over-wintering areas is primarily focused on the selection and development of new grape varieties, grape quality improvement and efficient cultivation techniques, key technology innovation and application of the wine industry chain, and little research has been conducted in the field of grape ecology [22]. This research aims to understand the economic and ecological value of the grape industry. Based on this, we have made an evaluation system for the value of the ecosystem service function of vineyards and conducted a systematic analysis. Our research will contribute to the sustainable development of the grape industry in soil-burial over-wintering areas.

\section{Research Areas and Research Methods}

\subsection{Research Areas}

As shown in Figure 2. Hongsibu $\left(105^{\circ} 43^{\prime} 45^{\prime \prime} \mathrm{E}, 37^{\circ} 28^{\prime} 08^{\prime \prime} \mathrm{N}\right)$ is located in the protected area of the National Geographical Declaration of Wine Grapes in the eastern foothills of Helan Mountain, Ningxia. This area is a temperate arid climate zone, and the continental climate is readily apparent. The annual average rainfall is $277 \mathrm{~mm}$, and the annual mean evaporation is $2050 \mathrm{~mm}$. The annual average temperature is $8.4^{\circ} \mathrm{C}$, the average temperature in the growing season from May to October is $17.9^{\circ} \mathrm{C}$. The annual effective accumulated temperature $\left(\geq 10{ }^{\circ} \mathrm{C}\right)$ is above $3200{ }^{\circ} \mathrm{C}$, and the average frost-free period is more than 170 days, which can fully meet the conditions of middle-late maturity grape cultivation [18].
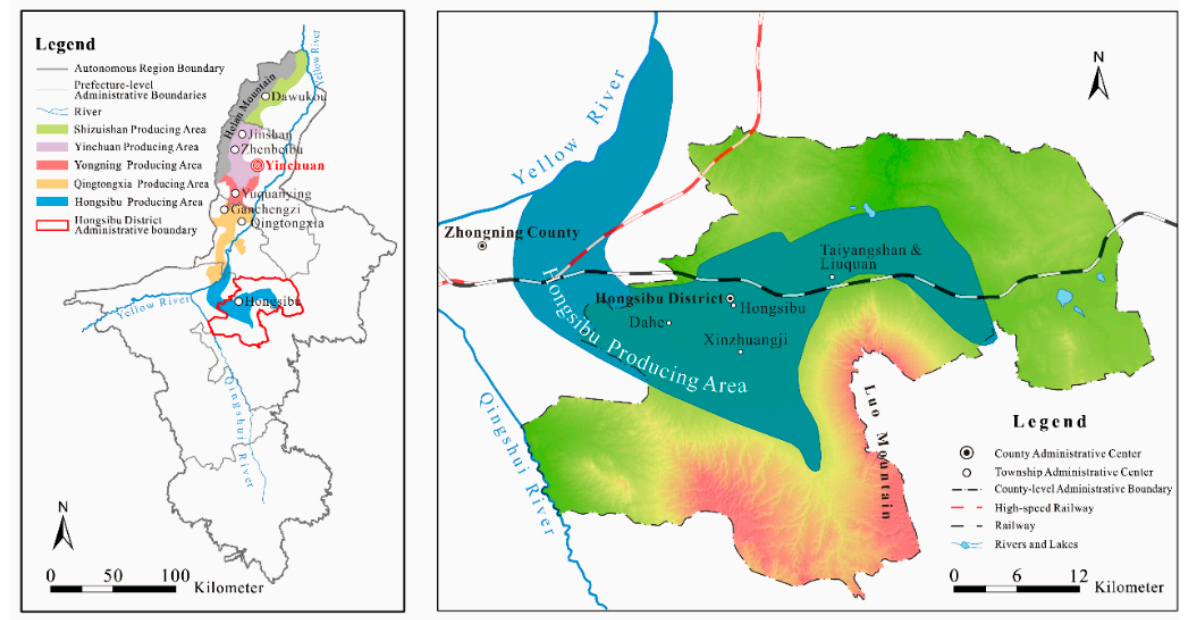

Figure 2. Location Map of Hongsibu District. The eastern foothills of Helan Moutain Region, Ningxia, is an internationally famous wine grapes-producing area, including five wine grapes sub-regions. The Hongsibu producing area is one of them.

\subsection{Research Methods}

Currently, there are many ways to evaluate ecosystem service functions, but evaluation systems for the ecosystem service functions of the grape industry are rare [23-27]. The method of this study is based on the classification of ecosystem services functions in China by Xie et al. [28]. For the first time, the ecosystem service functions of the grape industry are summarized into four first-level and 10 s-level indicator types as alluded to in the "Forest Ecosystem Service Function Evaluation Standards" (LY/T1721-2008) and China's economic forest ecosystem service value evaluation methods [29]. The evaluation index system of the grape ecosystem service functions is shown in Table 1. 
Table 1. The evaluation index system of the grape ecosystem service functions.

\begin{tabular}{|c|c|c|c|c|}
\hline \multicolumn{2}{|c|}{ Ecosystem Service Functions } & \multirow{2}{*}{ Evaluation Index } & \multirow{2}{*}{ Calculation Formula } & \multirow{2}{*}{ Parameter Description } \\
\hline Level 1 Indicators & Level 2 Indicators & & & \\
\hline \multirow{2}{*}{ Supply service } & \multirow{2}{*}{ Food production } & Value of grape & $\mathrm{Vf}=\mathrm{P} \cdot \mathrm{A} \cdot \mathrm{M}-\mathrm{Ci}$ & $\begin{array}{l}\text { P: the vineyard yield; A: the vineyard area; } \mathrm{M} \text { : the } \\
\text { market price of grapes; Ci: the cost input. }\end{array}$ \\
\hline & & Value of wine & $\mathrm{Vw}=\mathrm{B} \cdot \mathrm{C}-\mathrm{Ci}$ & $\begin{array}{l}\text { B: the single bottle price of wine; } \mathrm{C} \text { : the total wine } \\
\text { production; } \mathrm{Ci} \text { : the cost input. }\end{array}$ \\
\hline \multirow{7}{*}{$\begin{array}{l}\text { Regulatory } \\
\text { service }\end{array}$} & $\begin{array}{l}\text { Carbon fixation and } \\
\text { oxygen release }\end{array}$ & Value of carbon fixation & $V_{c}=\mathrm{Pc} \cdot \mathrm{A} \cdot(\mathrm{Upc}+\mathrm{Udc})$ & $\begin{array}{l}\text { Pc: the carbon fixation price; Upc: the carbon } \\
\text { storage above the vineyard; Udc: the carbon } \\
\text { storage above the vineyard. }\end{array}$ \\
\hline & & Value of oxygen release & $V_{0}=\mathrm{Po} \cdot \mathrm{N} \cdot \mathrm{A} \cdot \mathrm{b}$ & $\begin{array}{l}\text { Po: the price of oxygen; } \mathrm{N} \text { : the net } \mathrm{CO}_{2} \text { exchange } \\
\text { amount of the vineyard ecosystem; } \mathrm{b} \text { : the } \\
\text { proportionality coefficient, which is } 0.73 \text {. }\end{array}$ \\
\hline & Water holding & Value of water holding & $V w=(R-E) \cdot A \cdot P$ & $\begin{array}{l}\text { R: the average rainfall; E: the average annual } \\
\text { evapotranspiration; P: the unit water storage cost. }\end{array}$ \\
\hline & $\begin{array}{l}\text { Water conservation } \\
\text { and efficiency }\end{array}$ & Value of water conservation & $V w=(X-x) \cdot A \cdot P$ & $\begin{array}{c}X: \text { the average water used for grape irrigation; } x \text { : } \\
\text { the average water used for agricultural irrigation; } \\
\text { P: the average price of crop water. }\end{array}$ \\
\hline & \multirow{3}{*}{ Air purification } & $\begin{array}{l}\text { Value of negative } \\
\text { ion production }\end{array}$ & $\begin{array}{l}\mathrm{Vi}=52.56 \times 1014 \times \\
\mathrm{A} \cdot \mathrm{H} \cdot \mathrm{K}(\mathrm{Q}-600) / \mathrm{L}\end{array}$ & $\begin{array}{l}\text { H: the stand height; K: the cost of production of } \\
\text { negative ions; Q: the concentration of negative ions } \\
\text { in the forest; L: the retention time of negative ions; } \\
600 \text { is the lowest air negative ion concentration that } \\
\text { is beneficial to human health; }\end{array}$ \\
\hline & & $\begin{array}{l}\text { Value of absorption of } \\
\text { harmful gases }\end{array}$ & $\begin{array}{c}\mathrm{Vh}=\Sigma \mathrm{Ki} \cdot \mathrm{Qi} \cdot \mathrm{A} \\
\left(\mathrm{i}=\mathrm{SO}_{2}, \mathrm{NO}_{\mathrm{x}}, \mathrm{HF}_{\mathrm{x}}\right)\end{array}$ & $\begin{array}{l}\text { Ki: the unit price of pollution treatment unit; Qi: } \\
\text { the amounts of pollutants absorbed per unit area } \\
\text { of vineyard. }\end{array}$ \\
\hline & & Value of dust retention & $\mathrm{Vd}=\mathrm{K} \cdot \mathrm{Q} \cdot \mathrm{A}$ & $\begin{array}{l}\text { K: the unit price of the control cost of dust } \\
\text { reduction; Q: the amount of dust reduction } \\
\text { blocked by the vineyard per unit area. }\end{array}$ \\
\hline \multirow{4}{*}{ Support service } & \multirow[t]{2}{*}{ Soil conservation } & Value of soil fixation & $\mathrm{Vs}=\mathrm{A} \cdot \mathrm{C} \cdot\left(\mathrm{X}_{2}-\mathrm{X}_{1}\right)$ & $\begin{array}{l}\text { C: the soil conservation price; } X_{2} \text { : the annual soil } \\
\text { erosion modulus of the original topography; } X_{1} \text { : } \\
\text { the annual soil erosion modulus after the grapes } \\
\text { is planted. }\end{array}$ \\
\hline & & Value of retaining fertilized & $\begin{array}{l}\mathrm{Vf}=\sum \mathrm{A} \cdot \mathrm{Ci} \cdot \mathrm{Pi} \\
\quad\left(\mathrm{X}_{2}-\mathrm{X}_{1}\right) \\
(\mathrm{i}=\mathrm{N}, \mathrm{P}, \mathrm{K}, \mathrm{O})\end{array}$ & $\begin{array}{l}\text { Ci: the pure content of } \mathrm{N}, \mathrm{P}, \mathrm{K} \text { and } \mathrm{O} \text { in the } \\
\text { vineyard soil; } \mathrm{Pi} \text { : the price of } \mathrm{N}, \mathrm{P}, \mathrm{K} \text { and } \mathrm{O} \text {. }\end{array}$ \\
\hline & $\begin{array}{l}\text { Nutrient } \\
\text { accumulation }\end{array}$ & $\begin{array}{l}\text { Value of nutrient } \\
\text { accumulation }\end{array}$ & $\begin{array}{l}\mathrm{Vn}=\mathrm{A} \cdot \mathrm{Ci} \cdot \mathrm{Pi} \\
(\mathrm{i}=\mathrm{N}, \mathrm{P}, \mathrm{K})\end{array}$ & $\begin{array}{c}\text { Ci: the annual pure content of } \mathrm{N}, \mathrm{P} \text { and } \mathrm{K} \text { in grape } \\
\text { plants; } \mathrm{Pi} \text { is the price of N, } \mathrm{P} \text { and } \mathrm{K} .\end{array}$ \\
\hline & Biodiversity & Value of biodiversity & $\mathrm{Vb}=\mathrm{S} \cdot \mathrm{A}$ & $\begin{array}{l}\text { S: the protection value of annual biological species } \\
\text { resources per unit area of vineyard. }\end{array}$ \\
\hline \multirow{2}{*}{ Cultural service } & $\begin{array}{l}\text { Ecological poverty } \\
\text { alleviation }\end{array}$ & Value of employment & $\mathrm{Ve}=\mathrm{P} \cdot \mathrm{N}$ & \multirow{2}{*}{$\begin{array}{l}\text { P: the annual salary income per capita; } \mathrm{N} \text { : the total } \\
\text { number of people driving employment. } \\
\text { P: the annual per capita tourism expenditure; } \mathrm{N} \text { : } \\
\text { the total number of tourists }\end{array}$} \\
\hline & Ecotourism & Value of tourism & $\mathrm{Vt}=\mathrm{P} \cdot \mathrm{N}$ & \\
\hline
\end{tabular}

\subsection{Data Sources}

The data in this study are derived from: (1) relevant statistics from the Water Resources Department of Ningxia Hui Autonomous Region; (2) statistics from the Statistics Bureau of Ningxia Hui Autonomous Region; (3) social and public data released by the Grape Industry Development Bureau of Ningxia Hui Autonomous Region; (4) statistical data of the Grape Industrial Office of Hongsibu District Agricultural and Rural Bureau; (5) data obtained at vineyards and wineries through interviews and surveys.

\subsection{Data Standardization Procession}

Using the sampling survey method, we randomly selected 108 grape growers and 10 chateaus to obtain source data on evaluation indicators of the comprehensive benefits. The actual value of each indicator was then calculated using the formulas listed in Table 1.

\section{Results}

As of the end of 2018, the total grape planting area in Hongsibu has reached 7633.33 ha under conventional cultivation management, of which 7066.67 ha for wine grapes and 566.67 ha for table grapes. 


\subsection{Value of Ecosystem Service Function}

\subsubsection{Supply Service}

Food Production Function

We referenced the research by Zhang and Lei on the status of the grape industry in Hongsibu, and the relevant data in 2018 was provided by the Grape Industrial Office of Hongsibu District Agricultural and Rural Bureau [30,31]. The results of this evaluation are shown in Table 2.

Table 2. Food production function value of Hongsibu's grape industry.

\begin{tabular}{|c|c|c|c|c|c|}
\hline \multicolumn{2}{|c|}{ Evaluation Index } & \multirow{2}{*}{$\begin{array}{c}\text { Planting Distribution (ha) } \\
\text { Chateau }^{\mathrm{a}}\end{array}$} & \multirow{2}{*}{$\begin{array}{c}\text { Yield (kg·ha-1) } \\
3000 \sim 6000\end{array}$} & \multirow{2}{*}{$\begin{array}{c}\begin{array}{c}\text { Unit Selling Price } \\
\left(¥ \cdot \mathbf{k g}^{-\mathbf{1})}\right.\end{array} \\
5.0 \sim 10.0\end{array}$} & \multirow{2}{*}{$\begin{array}{c}\begin{array}{c}\text { Earnings } \\
\text { (Million } ¥)\end{array} \\
174\end{array}$} \\
\hline \multirow{3}{*}{ Grape } & & & & & \\
\hline & Wine grape & Farmer ${ }^{b}$ & $12,000 \sim 15,000$ & $3.0 \sim 5.0$ & 102 \\
\hline & Table grape & Chateau \& Farmer & $22,500 \sim 30,000$ & $5.0 \sim 7.0$ & 89.3 \\
\hline
\end{tabular}

a The first ingredient that defines a chateau owning a vineyard in viticultural suitable zone. In the table, chateau refers to a vineyard built by the chateau owner. ${ }^{b}$ In the table, farmer refers to a vineyard built by the farmer.

As Table 2 indicates, the income of the fruits production function of the grape industry ecosystem in Hongsibu was $¥ 365.3$ million ( $¥$ is the symbol for RenMinBi, Yuan.). Considering the large initial investment in the vineyard, the cost of grapes only uses the labor and material costs for the year being analyzed. Research by Yang and Gao indicated that investment in grapes ranges from 12,500 to $15,000 ¥ \cdot \mathrm{ha}^{-1}$ [32]. The grape industry in Hongsibu invested $¥ 105$ million, and the annual output value of the grapes was $¥ 260.3$ million in 2018. In addition, according to the data provided by the Industrial Office of Hongsibu District Agricultural and Rural Bureau, the annual processing capacity of the Hongsibu's grape industry reached 35 million $\mathrm{kg}$ in 2018, with an annual output of 8 million bottles of finished wine and an output value of $¥ 400$ million in profit. The total value of functional indicators of food production was $¥ 660.3$ million. The output value of grapes and fruits accounts for $39.42 \%$ of the total value of food production, and the output value of wine accounts for $60.58 \%$ of the total value of food production.

\subsubsection{Regulator Service}

\section{Carbon Fixation and Oxygen Release Function}

We referenced research by Guo and others on the net $\mathrm{CO}_{2}$ exchange of vineyard ecosystems in the soil-burial over-wintering areas [33,34]. The amount of oxygen released by the grapes was $648 \mathrm{~g} \cdot \mathrm{m}^{-2}$ during the main growth period. The ecological benefits of carbon fixation and oxygen release adopt the Chinese afforestation cost method. The price of carbon is $273.3 ¥ \cdot \mathrm{t}^{-1}$, and the price of oxygen is $369.7 ¥ \cdot \mathrm{t}^{-1}$. The results of this evaluation are shown in Table 3.

Table 3. Carbon fixation and oxygen release function value of Hongsibu's grape industry.

\begin{tabular}{|c|c|c|c|c|c|c|}
\hline \multicolumn{2}{|c|}{ Evaluation Index } & \multirow{3}{*}{$\begin{array}{l}\text { Design Formulas } \\
\begin{aligned} V_{c}=\text { Pc } \cdot A \cdot U p c \\
V_{c}=\text { Pc } \cdot A \cdot U d c\end{aligned}\end{array}$} & \multirow{3}{*}{$\begin{array}{c}\begin{array}{c}\text { Contribution } \\
\text { Per Unit Area } \\
\left(\mathbf{g} \cdot \mathbf{m}^{-2}\right)\end{array} \\
488 \\
326\end{array}$} & \multirow{3}{*}{$\begin{array}{c}\begin{array}{c}\text { Total } \\
\text { Contribution } \\
\text { Amount (t) }\end{array} \\
3.72 \times 10^{4} \\
2.49 \times 10^{4} \\
\end{array}$} & \multirow{3}{*}{$\begin{array}{c}\begin{array}{c}\text { Unit Price } \\
\left(¥ \cdot \mathbf{t}^{-\mathbf{1})}\right.\end{array} \\
273.3\end{array}$} & \multirow{3}{*}{$\begin{array}{c}\begin{array}{c}\text { Earnings } \\
\text { (million } ¥ \text { ) }\end{array} \\
10.2 \\
6.6\end{array}$} \\
\hline & Aboveground part & & & & & \\
\hline Carbon fixation & Underground part & & & & & \\
\hline \multicolumn{2}{|c|}{ Oxygen release } & $\mathrm{Vo}=\mathrm{Po} \cdot \mathrm{N} \cdot \mathrm{A} \cdot \mathrm{b}$ & 648 & $4.95 \times 10^{4}$ & 369.7 & 18.3 \\
\hline
\end{tabular}

Vineyard is a carbon sink during the main growth period. The aboveground part of the sink is mainly concentrated in annual organs (fruits, etc.) and perennial organs (trunk, etc.). The underground part of the sink is mainly concentrated in roots and soil. As Table 3 indicates, the carbon fixation and oxygen release value of the grape industry ecosystem in Hongsibu is $¥ 35.1$ million, of which the carbon fixation value is $¥ 16.8$ million, accounting 
for $47.86 \%$ of the total value of carbon fixation and oxygen release. The value of the oxygen released is $¥ 18.3$ million, accounting for $52.14 \%$ of the total value of carbon fixation and oxygen release.

\section{Water Holding Function}

Statistics provided by the Water Resources Department of Ningxia indicated that the annual average evapotranspiration of the grape production area in the eastern foothills of Helan Mountain is $184 \mathrm{~mm}$. The annual rainfall in Hongsibu production area is $277 \mathrm{~mm}$. Based on the lowest transaction price of $0.818 ¥ \cdot \mathrm{m}^{-3}$ calculated by the Ningxia Academy of Water Sciences as the base price, we used the water balance method to calculate it [35]. The total amount of water conserved by the grape industry ecosystem in Hongsibu is 7.1 million $\mathrm{m}^{3}$, and the ecological economic benefits generated by the water conservation are $¥ 5.81$ million.

\section{Water Conservation and Efficiency Function}

Wang and Song showed that the annual amount of irrigation water used in the Hongsibu irrigation area is $5710 \mathrm{~m}^{3} \cdot \mathrm{ha}^{-1}$, and the annual irrigation water in grape is $1500 \mathrm{~m}^{3} \cdot \mathrm{ha}^{-1}[26,36]$. Compared with other crops, the grape aquatic production value is $135 ¥ \cdot \mathrm{t}^{-1}$, which is 4.2 , 7.6, 38.8 and 41.8 times the output value of wolfberry (Lycium barbarum L), potato (Solanum tuberosum L), corn (Zea mays L) and wheat (Triticum aestioum L), respectively [36]. Statistics from the Water Resources Department of Ningxia indicated that the price of different crops before the reform was $0.22 ¥ \cdot \mathrm{m}^{-3}$, and the ecological and economic benefits of water-saving and efficiency improvement of the Hongsibu grape industry ecosystem were $¥ 7.08$ million.

\section{Air Purifying Function}

The index of negative ions in the air in vineyard ecosystems is based on previous studies on negative ions in the air of different types of vegetation $[37,38]$. The amount of harmful gases absorbed and the treatment costs are based on the results of Ma [39]. The results of this evaluation are shown in Table 4.

Table 4. Atmospheric purification function value of Hongsibu's grape industry.

\begin{tabular}{|c|c|c|c|c|c|}
\hline \multicolumn{2}{|c|}{ Evaluation Index } & Design Formulas & $\begin{array}{l}\text { Unit price }\left(¥ \cdot \mathrm{kg}^{-1}\right. \\
\left.\& ¥ \cdot 10^{-18} \cdot \text { unit }^{-1}\right)\end{array}$ & $\begin{array}{l}\text { Total Contribution } \\
\text { Amount (kg \& unit) }\end{array}$ & Earnings (¥) \\
\hline \multicolumn{2}{|c|}{ Negative ion production } & $\begin{array}{l}\mathrm{Vi}=52.56 \times 1014 \times \\
\mathrm{A} \cdot \mathrm{H} \cdot \mathrm{K} \cdot(\mathrm{Q}-600) / \mathrm{L}\end{array}$ & 7.29 & $5.69 \times 1020$ & 4150 \\
\hline \multirow{3}{*}{$\begin{array}{l}\text { Absorption of } \\
\text { harmful gases }\end{array}$} & Absorption of $\mathrm{SO}_{2}$ & $\mathrm{VsO}_{2}=\mathrm{KsO}_{2} \cdot \mathrm{QsO}_{2} \cdot \mathrm{A}$ & 0.6 & 687,000 & 412,000 \\
\hline & Absorption of $\mathrm{NO}_{\mathrm{X}}$ & $\mathrm{V}_{\mathrm{NOx}}=\mathrm{K}_{\mathrm{NOX}} \cdot \hat{\mathrm{Q}}_{\mathrm{NOX}} \cdot \mathrm{A}$ & 0.9 & 509,000 & 458,000 \\
\hline & Absorption of HF & $\mathrm{V}_{\mathrm{HF}}=\mathrm{K}_{\mathrm{HF}} \cdot \mathrm{Q}_{\mathrm{HF}} \cdot \mathrm{A}$ & 0.6 & 6100 & 3660 \\
\hline \multicolumn{2}{|c|}{ Dust retention } & $\mathrm{Vd}=\mathrm{K} \cdot \mathrm{Q} \cdot \mathrm{A}$ & 170 & 68,700 & $11,700,000$ \\
\hline
\end{tabular}

The unit price of negative ion production is $¥ \cdot 10^{-18} \cdot$ unit $^{-1}$. The unit price of absorption of harmful gases and dust retention is $¥ \cdot \mathrm{kg}^{-1}$.

Table 4 indicates that the annual purification value of the grape industry ecosystem in Hongsibu is $¥ 12.58$ million. Among them, the value of providing negative ions is $¥ 4150$, accounting for $0.03 \%$ of the total value of purifying the atmosphere; the value of absorption of $\mathrm{SO}_{2}$ is $¥ 412,000$, accounting for $3.28 \%$ of the total value of purifying the atmosphere. The value of absorption of NOx is $¥ 458,000$, accounting for $3.65 \%$ of the total value of purified air. The value of HF is $¥ 3660$, accounting for $0.03 \%$ of the total value of purifying the atmosphere. The value of retarding the fall of dust is $¥ 11.7$ million, accounting for $93 \%$ of the total value of purifying the atmosphere.

\subsubsection{Support Services}

Soil Conservation Function

Wang and Gao conducted research on the soil and water conservation monitoring of Hongsibu [40,41]. The original landform soil erosion modulus of the Hongsibu irrigation 
area was $3.50 \times 10^{-3} \mathrm{t} \cdot \mathrm{m}^{-2} \cdot \mathrm{year}^{-1}$, and the allowable soil loss in the irrigation area after the development of forest and grasscover management is $8.00 \times 10^{-4} \mathrm{t} \cdot \mathrm{m}^{-2} \cdot \mathrm{year}^{-1}$. Xiao et al. found that the price of soil conservation is $6.52 ¥ \cdot \mathrm{t}^{-1}$ [42]. The research of Wang on the mechanisms of nitrogen, phosphorus, potassium and those in the soil of the grape production area in the eastern foothills of Helan Mountain indicated that the content of organic matter in the soil of the vineyard is $10.79 \mathrm{~g} \cdot \mathrm{kg}^{-1}$ [43]. We converted the total amount of standardized ammonium diammonium phosphate and potassium chloride to facilitate their conversion into pure nitrogen, phosphorus, and potassium. The ratios of the fertilizers are $132 / 28,132 / 31$, and $75 / 39$. The price of chemical fertilizers is calculated based on the average cost of Chinese chemical fertilizers equaling $2.55 \times 10^{3} ¥ \cdot \mathrm{t}^{-1}$ [44]. The ratio of general fuel wood to soil organic matter is 2:1, and the opportunity cost per ton of fuel wood is $¥ 51.3$ [45]. The results of this evaluation are shown in Table 5 .

Table 5. Atmospheric purification function value of Hongsibu's grape industry.

\begin{tabular}{|c|c|c|c|c|c|}
\hline \multicolumn{2}{|c|}{ Evaluation Index } & Design Formulas & $\begin{array}{c}\text { Unit Price } \\
\left(¥ \cdot t^{-1)}\right.\end{array}$ & $\begin{array}{c}\text { Total } \\
\text { Contribution } \\
\text { Amount (t) }\end{array}$ & $\begin{array}{c}\text { Earnings } \\
(¥)\end{array}$ \\
\hline \multicolumn{2}{|c|}{ Soil fixation } & $\mathrm{Vs}=\mathrm{A} \cdot \mathrm{C} \cdot\left(\mathrm{X}_{2}-\mathrm{X}_{1}\right)$ & 6.52 & 206,000 & $1,340,000$ \\
\hline \multirow{4}{*}{ Fertilizer retained } & Retention of organic & $\mathrm{V}_{\mathrm{O}}=\mathrm{A} \cdot\left(\mathrm{X}_{2}-\mathrm{X}_{1}\right) \cdot \mathrm{C}_{\mathrm{O}} \cdot \mathrm{P}_{\mathrm{O}}$ & 103 & 2220 & 227,000 \\
\hline & Retention of nitrogen & $\mathrm{V}_{\mathrm{N}}=\mathrm{A} \cdot\left(\mathrm{X}_{2}-\mathrm{X}_{1}\right) \cdot \mathrm{C}_{\mathrm{N}} \cdot \mathrm{P}_{\mathrm{N}}$ & \multirow{3}{*}{2550} & 3.48 & 88,700 \\
\hline & Retention of phosphate & $V_{P}=A \cdot\left(X_{2}-X_{1}\right) \cdot C_{P} \cdot P_{P}$ & & 2.74 & 69,900 \\
\hline & Retention of potassium & $\mathrm{V}_{\mathrm{K}}=\mathrm{A} \cdot\left(\mathrm{X}_{2}-\mathrm{X}_{1}\right) \cdot \mathrm{C}_{\mathrm{K}} \cdot \mathrm{P}_{\mathrm{K}}$ & & 18.9 & 481,000 \\
\hline
\end{tabular}

Table 5 indicates that the annual soil conservation value of the grape industry ecosystem in Hongsibu is $¥ 2.21$ million. Among them, the value of solid soil is $¥ 1.34$ million, accounting for $60.74 \%$ of the total value of conservation soil. The value of soil is $¥ 867,000$, accounting for $39.26 \%$ of the total benefit of soil conservation.

Nutrient Accumulation Function

Based on the results of research by Ma, on the nutrient accumulation of grapes in soil-burial over-wintering areas, the distribution of nitrogen, phosphorus, and potassium in various parts of grape plants is shown in Table 6 [46]. The N, P, K content $\left(\mathrm{kg} \cdot \mathrm{hm}^{-2}\right)=\mathrm{N}$, $\mathrm{P}, \mathrm{K}$ content $\left(\mathrm{g} \cdot \mathrm{kg}^{-1}\right) \times$ dry weight $\left(\mathrm{kg} \cdot \mathrm{strain}^{-1}\right) \times$ number of plants $\left(\right.$ strain $\left.\cdot \mathrm{ha}^{-1}\right) \times 10^{-3}$.

Table 6. Grape plant nutrient accumulation and distribution chart.

\begin{tabular}{cccccccccc}
\hline $\begin{array}{c}\text { Nutrient } \\
\left(\mathbf{k g} \cdot \mathbf{h a}^{-\mathbf{1}} \mathbf{)}\right.\end{array}$ & Leaves & Petiole & Shoot & Trunk & $\begin{array}{c}\text { Vine } \\
\text { Root }\end{array}$ & Fruit & Total & Earnings (¥) & $\begin{array}{c}\text { Value } \\
\text { Composition (\%) }\end{array}$ \\
\hline $\begin{array}{c}\text { Nitrogen content of } \\
\text { the grapevine }\end{array}$ & 53.5 & 2.8 & 36.0 & 26.1 & 17.6 & 60.7 & 196.7 & $3,830,000$ & 41.50 \\
$\begin{array}{c}\text { Phosphate content } \\
\text { of the grapevine }\end{array}$ & 28.5 & 3.6 & 24.1 & 13.2 & 17.6 & 19.7 & 106.7 & $2,080,000$ & 22.52 \\
$\begin{array}{c}\text { Potassium content } \\
\text { of the grapevine }\end{array}$ & 29.3 & 19.2 & 42.7 & 15.2 & 8.6 & 55.2 & 170.5 & $3,320,000$ & 35.98 \\
\hline
\end{tabular}

Table 6 indicated that the total accumulation of annual nutrients in the vines of the grape industry ecosystem in Hongsibu is $473.9 \mathrm{~kg} \cdot \mathrm{ha}^{-1}$. The total grapevines planting area in Hongsibu was 7633.33 ha. The total accumulation of annual nutrients in the vines of the grape industry ecosystem in Hongsibu is 36.2 million $\mathrm{kg}$, and the value is $¥ 9.21$ million. Among them, the accumulated amount of nitrogen in the vine is 15 million $\mathrm{kg}$, with a value of $¥ 3.83$ million, accounting for approximately $41.50 \%$ of the total benefits of the accumulation of material. The accumulated amount of phosphorus in the vine is 8.14 million $\mathrm{kg}$, and the value is $¥ 2.08$ million, accounting for $22.52 \%$ of the total benefits of the accumulation of material. The accumulated amount of potassium in the vine is 
13 million $\mathrm{kg}$, and the value is $¥ 3.32$ million, accounting for approximately $35.98 \%$ of the total benefits of the accumulation of material.

\section{Biodiversity Function}

Wang and other researchers who have evaluated economic forest ecosystem services in China have reported that the Shannon-Wiener index is an important tool to calculate the conservation value of biological species resources [29]. When the index is 2 to 3 , the conservation value of biodiversity is $20,000 ¥ \cdot \mathrm{ha}^{-1} \cdot \mathrm{year}^{-1}$. When the index is 3 to 4 , the conservation value of biodiversity is $30,000 ¥ \cdot \mathrm{ha}^{-1} \cdot$ year $^{-1}$. The research on vineyard soil microbial communities by $\mathrm{Si}$, indicated that the diversity index of soil microbial communities in clear plowed vineyards is between 2 and 3 [47]. Therefore, we can estimate that the value of the annual biodiversity function of the grape industry ecosystem in Hongsibu is $¥ 153$ million.

\subsubsection{Cultural Service}

Ecological Poverty Alleviation Function

Based on the research by Yang and Gao on the status of Hongsibu's grape industry, the grape labor is 0.7 ha per person [32]. The entire grape base area of Hongsibu is 7633 ha, which requires 10,904 people to stabilize employment. The annual income is calculated at $¥ 15,000$ per person, which can increase the income of the production area and surrounding farmers by $¥ 164$ million. The grape industry has become a pillar industry to alleviate poverty in soil-burial over-wintering areas.

\section{Ecotourism Function}

Based on the Hongsibu District People's Government Work Report, the area received 440,000 tourists and achieved a comprehensive tourism income of $¥ 16.6$ million in 2017 . Hongsibu received 471,000 tourists throughout the year by holding a picking festival for special industries in 2018. Based on the per capita tourism expenditure in 2017, it realized a comprehensive tourism income of $¥ 17.77$ million in 2018 .

\subsection{Direct and Indirect Benefits}

As Table 7 indicates, the total current benefits of the grape industry ecosystem service functions are $¥ 1067$ million, of which direct economic benefits are $¥ 660$ million and indirect ecological benefits are $¥ 407$ million. Ecological benefits account for $38.14 \%$ of the current total benefits of the grape industry ecosystem service functions. The value ranking of the first-level function types is as follows: supply services $>$ cultural services $>$ support services $>$ regulatory services. The ranking of the value of second-level function types is as follows: food production $>$ Ecological poverty alleviation $>$ biodiversity $>$ carbon fixation and oxygen release $>$ ecotourism $>$ air purification $>$ nutrient accumulation $>$ water conservation and efficiency $>$ water holding $>$ soil conservation.

\subsection{Current and Potential Benefits}

We designate the current benefits of the grape industry ecosystem service functions, and the potential benefits of the grape industry ecosystem service functions under different models of cultivation technology. This study only considered the burial-free cultivation technology, inter-row grass technology, and suspending grape branches after winter pruning technology of the grape industry in the soil-burial over-wintering areas. By analyzing the data in research by Xue, it was known that the burial-free cultivation as an overwintering measure for soil-burial over-wintering areas reduced the average wintering cost from $22 \%$ of the annual management to $6.5 \%$. Converting it into the value of food production, the implementation of burial-free cultivation technology increased the value of food production by $¥ 16.3$ million in soil-burial over-wintering areas. 
Table 7. Direct benefits and indirect benefits of grape industry ecosystem service functions in Hongsibu.

\begin{tabular}{|c|c|c|c|c|c|}
\hline Ecological Functions & Level 1 Type & Level 2 Type & $\begin{array}{l}\text { Ecological Service } \\
\text { Value (Million } ¥ \text { ) }\end{array}$ & $\begin{array}{c}\text { Value } \\
\text { Composition (\%) }\end{array}$ & $\begin{array}{l}\text { Ecological Value } \\
\text { Composition (\%) }\end{array}$ \\
\hline Direct benefits & Supply service & Food production & 660.30 & 61.88 & 61.88 \\
\hline \multirow{9}{*}{ Indirect benefits } & \multirow{4}{*}{ Regulatory services } & Carbon fixation and oxygen release & 35.10 & 3.29 & \multirow{5}{*}{5.67} \\
\hline & & Water holding & 5.81 & 0.54 & \\
\hline & & Water conservation and efficiency & 7.08 & 0.66 & \\
\hline & & Air purification & 12.58 & 1.18 & \\
\hline & \multirow{3}{*}{ Support services } & Soil conservation & 2.21 & 0.21 & \\
\hline & & Nutrient accumulation & 9.21 & 0.86 & \multirow[t]{2}{*}{15.41} \\
\hline & & Biodiversity & 153.00 & 14.34 & \\
\hline & \multirow{2}{*}{ Cultural services } & Ecological poverty alleviation & 164.00 & 15.37 & \multirow{2}{*}{17.04} \\
\hline & & Ecotourism & 17.77 & 1.67 & \\
\hline
\end{tabular}

The technique of suspending grape branches in winter reduced the wind blowing on the soil surface particles, thereby reducing the amount of erosion by $75.85 \%$ [11]. Converting it into the value of solid soil, the implementation of suspending the grape branches after winter pruning technology increased the solid soil value by $¥ 1.02$ million in soil-burial over-wintering areas. In addition, the study found that the implementation of inter-row grass technology in soil-burial over-wintering areas significantly increased the content of soil organic matter. Compared with the control of clear cultivation, the inter-row grass soil organic matter content increased by $1.5 \mathrm{~g} \cdot \mathrm{kg}^{-1}$ [18]. Converting it into organic matter preservation value, the implementation of inter-row grass technology in soil-burial over-wintering areas, preserved the value of the fertilizer by $¥ 31,700$.

Moreover, the implementation of inter-row grasscover technology in vineyards significantly increased the richness of soil microbial communities, resulting in a $0-20 \mathrm{~cm}$ soil layer microbial community diversity index greater than three [41]. The implementation of inter-row grasscover technology in soil-burial over-wintering areas increased the biodiversity value by $¥ 76.3$ million following converting into this value. However, the vineyard inter-row grass technology reduced the soil water storage, and the average decline for two consecutive years reached $9.15 \%$ [42]. Following conversion into the value of water holding, the implementation of inter-row grass technology in vineyards reduced the value of conservation water by $¥ 532,000$. The potential benefits assessment does not cover all ecological service functions related to the current benefits, as some of the research has not been conducted in soil-burial over-wintering areas. The results of this evaluation are shown in Table 8.

Table 8. Current and potential benefits of the grape industry ecosystem service functions in Hongsibu.

\begin{tabular}{|c|c|c|c|c|c|}
\hline Ecological Functions & Level 1 Type & Level 2 Type & $\begin{array}{l}\text { Current Benefits } \\
\text { (Million } ¥)\end{array}$ & $\begin{array}{l}\text { Potential Benefits } \\
\text { (Million } ¥ \text { ) }\end{array}$ & $\begin{array}{l}\text { Potential Benefits } \\
\text { Composition (\%) }\end{array}$ \\
\hline Direct benefits & Supply service & Food production & 660.30 & 676.63 & 58.33 \\
\hline \multirow{9}{*}{ Indirect benefits } & \multirow{4}{*}{ Regulatory services } & Carbon fixation and oxygen release & 35.10 & / & \multirow{4}{*}{5.18} \\
\hline & & Water holding & 5.81 & 5.28 & \\
\hline & & Water conservation and efficiency & 7.08 & / & \\
\hline & & Air purification & 12.58 & / & \\
\hline & \multirow{3}{*}{ Support services } & Soil conservation & 2.21 & 3.26 & \multirow{3}{*}{20.82} \\
\hline & & Nutrient accumulation & 9.21 & / & \\
\hline & & Biodiversity & 153.00 & 229 & \\
\hline & \multirow{2}{*}{ Cultural services } & Ecological poverty alleviation & 164.00 & / & \multirow[b]{2}{*}{15.67} \\
\hline & & Ecotourism & 17.77 & / & \\
\hline
\end{tabular}

Table 8 indicates that the potential benefits of the grape industry ecosystem service function under the supporting cultivation technology are $¥ 92.85$ million. Combined with Table 7 , the total potential benefits of the grape industry ecosystem service that functions under supporting cultivation technologies are $¥ 1160$ million, of which direct economic benefits are $¥ 677$ million and indirect ecological benefits are $¥ 483$ million. Ecological benefits account for $41.67 \%$ of the total potential benefits of the grape industry ecosystem service functions. The value of first-level indicator types supports service functions exceeds those of cultural service functions, exerting a greater ecological value embodied in the richness of biodiversity. 


\section{Discussion}

Grapevine ecosystems both provide and rely upon important ecosystem service, which can be classified into four main categories: supply service, regulating service, supporting service and cultural service [48]. Understanding the value of ecosystem service function is necessary for soil-burial over-wintering areas, which is of great significance to the sustainable and healthy development of grape industry [36]. This research mainly evaluated the ecological service function value of grape industry in soil-burial over-wintering areas, and analyzed the direct and indirect ecological benefits of the grape industry. In addition, a comparative analysis of potential benefits and current benefits of the grape industry under some cultivation measures in the soil-burial over-wintering areas has been done, which provides a potential direction for subsequent research.

\subsection{Grape Industry Provides Important Ecosystem Service Value}

Grape ecosystem services confer benefits and costs, respectively, to agriculture. These are supplied by varied species and functional groups in grapevine yards over a range of scales, and influenced by human activities [48]. The grape industry ecosystem not only provides food for humans but also includes enormous environmental regulatory and ecological service functions in the soil-burial over-wintering areas [36]. Our research results showed that the value of food supply accounted for $61.88 \%$ of the entire grape industry ecosystem service value which was the greatest value of the grape industry ecosystem; these results were consistent with previous research results [36]. The second was cultural services. Among them, the value of ecological poverty alleviation contributes the most to the cultural service value. This shows that the development of the grape industry has increased the income of residents, and solve the employment problem of the poor effectively, thus producing significant social benefits [18].

However, the low value of eco-tourism was derived in this study. The reason may be that Hongsibu production area, on the eastern foot of Helan Mountain, is small. On the one hand, the superior local resources are significantly lower than the average level of the entire production area. On the other hand, the regional tourism industry is not well developed and is still lagging behind $[49,50]$. The potential role of biodiversity in the grape ecosystem can help provide economically relevant ecosystem services [19]. In this study, the functional value of biodiversity contributed the greatest to support service value, indicating that cultivating grapes help enrich the biodiversity in soil-burial overwintering areas. Microorganisms (bacteria, fungi, actinomycetes) are critical mediators of this ecosystem service. For example, bacteria enhance nitrogen availability through the fixation of nitrogen from the atmosphere. This occurs most often in plants that have symbiotic relationships with $\mathrm{N}$-fixing bacteria, but free-living soil bacteria fix nitrogen as well [51]. Microorganisms also enhance soil fertility by liberating nutrients from detrital organic matter (e.g., plant leaves) and retaining nutrients in their biomass that might otherwise be lost downstream [52]. Therefore, rich biodiversity is of great significance to the accumulation and circulation of soil nutrients.

However, in this study, although the biodiversity value of vineyards was much higher than that of sea buckthorn, the soil conservation value and nutrient accumulation value were only $¥ 2.21$ and $¥ 9.21$ million, respectively, which were far lower than the soil conservation value of sea buckthorn [53-55]. The reason may be that vineyard farming methods (such as burying and unearthed mechanical farming) will damage the soil surface, limiting soil conservation to a certain extent [11]. Grapevines are not only an economic forest, which produces fruits, but also a characteristic green forest, which is conducive to the improvement of the ecological environment, mainly through carbon fixation and oxygen release [36], water conservation and water-saving and efficiency-enhancing [56], as well as atmospheric purification [36].

Trees improve water infiltration within woodlands, and reduce surface runoff and soil salinization [57]. Wetlands and riparian vegetation can also improve water quality and attenuate floods [58]. In this study, the total value of water holding and water conservation 
of the vineyard accounted for $1.20 \%$ of the total value, which is still higher than many traditional local crops, such as corn, wheat, rice and potatoes [36]. It shows that grapes consume less water during cultivation and are suitable for planting in arid and semi-arid areas in northern China.

Carbon fixation and oxygen release as well as air purification are important parts of the regulation service function. In this study, carbon fixation and oxygen release accounted for a relatively high proportion of the regulation service value, followed by air purification. Studies found that total carbon storage of the Vitis vinifera 'Cabernet Sauvignon' vineyard ecosystem is $55.35 \mathrm{t} \cdot \mathrm{ha}^{-1}$, most of which is distributed in the soil surface (underground), and the remaining part is mainly distributed in the perennial, leaf and fruit parts of the vine (the aboveground) [59]. Grapes, as a protective forest in soil-burial over-wintering areas, are much more effective in cleaning the atmosphere than sea buckthorn, with a value of $¥ 1648$ per ha for grapes and only $¥ 54.9$ per ha for sea buckthorn [55].

\subsection{Grape Industry Plays an Important Role in Direct and Indirect Ecological Benefits}

Direct benefits mainly refer to the profit value of grape and wine; the indirect benefits are mainly reflected in the ecological benefits of the grape industry. In this study, the direct benefits of the grape industry accounted for $61.88 \%$ and the ecological benefits accounted for $38.12 \%$ of the total benefits of the ecosystem service value of the grape industry in soil-burial over-wintering areas. This indicates that the grape industry ecosystem not only provides direct benefits but also provides significant economic benefits for human society [36]. Among the ecological benefits, the value of ecological poverty alleviation was the highest, followed by the value of biodiversity. This shows that, in the context of the relatively fragile ecological environment of the soil-burial over-wintering areas, with the continuous expansion of the area of grape cultivation, the direct economic benefits are becoming more and more evident, while the ecological and biodiversity benefits it generates cannot be ignored [18]. Because of this, the importance of the long-term objectives of the vineyard system deserves to be considered. As a woody perennial crop, grapevines can be considered a service crop in the agricultural landscape, i.e., providing more overall services than products for sale. This cash crop is prone to delivering ecosystem services agro-ecosystems [18]. In addition to their ability to increase soil organic matter and fertility, and reduce runoff and erosion processes, service crops provide a large variety of ecosystem services in vineyards such as weed control, pest and disease regulation, water supply, water purification, improvement of field trafficability and maintenance of soil biodiversity [19]. It contributes to the protection and improvement of the ecological environment and is of great importance to the goal of sustainable development.

\subsection{Grape Industry Has Great Potential Benefits}

This study conducted an assessment and analysis of the ecosystem services value of vineyards with three cultivation techniques, showing that there is important potential benefits could be exploited in the grape industry. To a large extent, these potential benefits depend on the strategies of farmers and the tactical operations they set up [60]. We designated the current benefits of the grape industry ecosystem service functions, and the potential benefits of the grape industry ecosystem service functions under different models of cultivation technology. Only the burial-free cultivation technology, inter-row grass technology, and suspending grape branches after winter pruning technology of the grape industry in the soil-burial over-wintering areas were considered in this study. The implementation of burial-free cultivation technology added $¥ 16.3$ million to food production value in soil-burial over-wintering areas. As part of the conservation tillage, costs (for example, labor, facilities, and operating costs) are decreased by reducing winter burial and spring emergence tillage, thus increasing the value of food supply service [61].

In addition, mulching techniques may also decrease soil evaporation [62] and prevent runoff and erosion from vineyard soils [63]. The implementation of the suspending grape branches after using winter pruning technology in vineyards reduces the amount of wind 
blowing on soil surface particles and the amount of soil erosion [17], while increasing the value of soil conservation by $¥ 1.02$ million in soil-burial over-wintering areas. The implementation of inter-row grass technology in the soil-buried overwintering zone increased the value of fertilizer retention and biodiversity by $¥ 31.7$ and $¥ 76.3$ million, respectively, but reduced the value of water retention by $¥ 532,000$. This is due to the fact that the implementation of inter-row grass mulching in vineyards significantly increases the soil organic matter content and soil microbial community richness, but reduces soil water storage [12-14]. Several interventional strategies such as rational fertilization, cover crops, non-tillage, and other agronomic measures enhance soil structure and associated productivity, thereby improving the efficiency within the orchard ecosystem while simultaneously reducing net carbon emissions [19]. Therefore, it is possible to exploit the potential value of the vineyard ecosystem by changing some of the current cultivation practices.

Considering the potential value that can be realized, cultivators need to be managed, as does any other crop is grown with a direct economic purpose. The introduction of cultivation practices that help farmers overcome the problems often faced by vineyards (water loss, soil erosion and carbon emission) is developing, though it has not been systematically adopted by vineyard growers [18]. As the main reason for service crop rejection is still competition with grapevines, more research is needed to develop appropriate cultivation techniques according to the targeted services and tactical management options to achieve trade-offs between ecosystem service without impairing economic return of farmers [19].

Although this study quantitatively analyzed the current and potential benefits of the grape industry ecosystem service function in Hongsibu, due to the limitation of evaluation methods and data in the research process, not all the use values and non-use values of the system were evaluated, and the protection value, scientific research value, heritage value, and aesthetic value were absent from our study. Therefore, as far as the results of these evaluations are concerned, the actual ecological service value of the study area is much larger than the current results of this evaluation. In addition, during the process of evaluation, due to the lack of local research data for the evaluation of a single ecological function, some data indicators refer to the comparison of research results in other regions, which inevitably introduces certain errors. To more comprehensively and accurately evaluate the ecological benefits of the grape industry ecosystem service functions in the soil-burial over-wintering areas and minimize these types of errors, we need to explore the data in more detail and improve them in practice.

\section{Conclusions}

Among the four first-level functional values, supply services and cultural services account for the highest proportion. Among the 10 s-level functional values, food production, ecological poverty alleviation and biodiversity account for a relatively high proportion. Some cultivation measures, such as burial-free cultivation technology, inter-row grass technology, and suspending grape branches after winter pruning technology, increase the value of the ecosystem service function of grape industry and offer new opportunities to exploit the potential benefits of the grape industry. The development of the grape industry in the over-wintering areas help drive the local economy and employment, and provide income increases and poverty alleviation for the growers and solves the livelihood problem of the poor residents in sandy areas. Generally, the development of local grapevines industries effectively improves the local ecology, thus providing solutions to the dual pressures of poverty and environmental degradation, as well as providing a method of sustainable development worldwide.

Author Contributions: Conceptualization, Z.W., L.Z., Y.W., H.W. and H.L.; Data curation, Z.W., X.C., L.Z. and X.H.; Formal analysis, X.C.; Funding acquisition, H.W. and H.L.; Investigation, Z.W., L.Z., X.H. and Y.W.; Methodology, Z.W.; Project administration, H.W. and H.L. All authors have read and agreed to the published version of the manuscript. 
Funding: This work was supported by the National Key Research and Development Project, [2019YFD1002500], Key Research and Development Project of Shaanxi Province, [2020ZDLNY07-08].

Institutional Review Board Statement: Not applicable.

Informed Consent Statement: Not applicable.

Data Availability Statement: Data is contained within the article or references.

Acknowledgments: We appreciate the help of the Grape Industrial Office of Hongsibu District Agricultural and Rural Bureau with the collection of the occurrence data and its verification.

Conflicts of Interest: The authors declare no competing interests.

\section{References}

1. Pau, S. State of the vitivinicultural sector in 2019. In Proceedings of the OIV Press Conference, Paris, France, 23 April 2020.

2. Liu, F. Current status and development trent of viticulture in China. Deciduous Fruits 2017, 49, 1-4. [CrossRef]

3. Xue, T.T.; Han, X.; Zhang, H.J.; Wang, Y.; Wang, H.; Li, H. Effects of a biodegradable liquid film on winter chill protection of winegrape cultivars. Sci. Hortic. 2019, 246, 398-406. [CrossRef]

4. Wang, Z.L.; Xue, T.T.; Gao, F.F.; Zhang, L.; Han, X.; Wang, Y.; Hui, M.; Wu, D.; Li, H.; Wang, H. Intraspecific recurrent selection in V. vinifera: An effective method for breeding of high quality, disease-, cold-, and drought -resistant grapes. Euphytica 2021, 111-126. [CrossRef]

5. Yuan, Q.C.; Xu, L.M.; Ma, S.; Yu, C.C.; Duan, Z.Z.; Xing, J.J. Current situation and consideration of mechanization of grape planting in winter and soil cleaning in spring in northern China. Sino-Overseas Grapevine Wine 2017, 6, 66-67. [CrossRef]

6. Lisek, J.; Lisek, A. Cold Hardiness of Primary Buds of Wine and Table Grape Cultivars in Poland. S. Afr. J. Enol. Vitic. 2020, 41, 189-196. [CrossRef]

7. Atucha, A.; Hedtcke, J.; Workmaster, B.A. Pomology; Study Results from University of Wisconsin Update Understanding of Pomology (Evaluation of Cold-climate interspecific Hybrid Wine Grape Cultivars for the Upper Midwest). Agric. Week J. Am. Pomol. Soc. 2018, 72, 80-93.

8. Fennell, A. Freezing Tolerance and Injury in Grapevines. J. Crop. Improv. 2004, 10, 201-235. [CrossRef]

9. Wang, L.; Li, H.; Wang, H. Climatic regionalization of grape in China II: Wine grape varieties regionalization. Chin. Sci. Bull. 2017, 62, 1539-1554. [CrossRef]

10. Wang, L.; Hua, L.; Wang, H. Climatic regionalization of grape in China I: Indexes and methods. Chin. Sci. Bull. 2017, 62, 1527-1538. [CrossRef]

11. Wolff, M.W.; Alsina, M.M.; Stockert, C.M.; Khalsa, S.D.S.; Smart, D.R. Minimum tillage of a cover crop lowers net GWP and sequesters soil carbon in a California vineyard. Soil Tillage Res. 2018, 175, 244-254. [CrossRef]

12. Liu, S.; Wang, Z.L.; Zhang, J.X. Effects of within-row mulching on soil microsites in vineyard and fruit quality. J. Northwest $A F$ Univ. 2019, 47, 1-8. [CrossRef]

13. Li, C.; Wang, X.L.; Liu, S.; Li, H.; Zhang, J.X. Effects of Natural Herbage on Soil-nutrients, Enzyme Activities and Microorganisms in Vineyard of Helan Mountain's Eastern Foothills. Southwest China J. Agric. Sci. 2019, 32, 559-565. [CrossRef]

14. Xi, Z.M.; Li, H.; Long, Y.; Zhang, J.; Pang, X.L. Variation of Soil Microbial Populations and Relationships Between Microbial Factors and Soil Nutrients in Cover Cropping System of Vineyard. Acta Hortic. Sin. 2010, 37, 33-37. [CrossRef]

15. Xi, Z.M.; Li, H.; Zhang, Z.W.; Liu, Y.L.; Wei, G.L. Effect of green covering on vineyard microclimate and wine quality. J. Northwest Sci-Tech Univ. Agric. For. 2004, 32, 33-37. [CrossRef]

16. Wang, S.; Li, H.; Wang, H. Wind erosion prevention effect of suspending shoots on wires after winter pruning in soil-burying zones over-wintering. Trans. Chin. Soc. Agric. Eng. 2015, 31, 206-212. [CrossRef]

17. Wang, S. Effect of Shoots Windbreak on Vineyard Ecotope in Soil-Buried Cold-Proof Period; Northwest A\&F University: Yangling, China, 2015.

18. Zhang, L.; Wang, Z.; Xue, T.; Gao, F.; Wei, R.; Wang, Y.; Han, X.; Li, H.; Wang, H. Combating Desertification through the Wine Industry in Hongsibu, Ningxia. Sustainability 2021, 13, 5654. [CrossRef]

19. Garcia, L.; Celette, F.; Gary, C.; Ripoche, A.; Valdés-Gómez, H.; Metay, A. Management of service crops for the provision of ecosystem services in vineyards: A review. Agric. Ecosyst. Environ. 2018, 251, 158-170. [CrossRef]

20. Paiola, A.; Assandri, G.; Brambilla, M.; Zottini, M.; Pedrini, P.; Nascimbene, J. Exploring the potential of vineyards for biodiversity conservation and delivery of biodiversity-mediated ecosystem services: A global-scale systematic review. Sci. Total Environ. 2020, 706. [CrossRef]

21. Han, X.; Xue, T.; Liu, X.; Wang, Z.; Zhang, L.; Wang, Y.; Yao, F.; Wang, H.; Li, H. A Sustainable Viticulture Method Adapted to the Cold Climate Zone in China. Horticulturae 2021, 7, 150. [CrossRef]

22. Tian, S.F. The Development of Grape Industry and Technology in China. J. Agric. 2018, 8, 135-139.

23. Li, H.; Wang, H.; Aamp, N. A sustainable viticulture model adapting to the soil-bury over-wintering zone of China. Sino-Overseas Grapevine Wine 2018, 6, 68-73. [CrossRef] 
24. Liu, H.; Zhao, Q.; Zhang, L.; Li, Z.H. The Methods of Assessment for Valuation of Ecosystem Service. Environ. Ecol. Three Gorges 2011, 33, 29-34. [CrossRef]

25. Liu, Y.L.; Ma, J.J.; Jin, X.L.; Wang, B.Z.; Lin, J.Q.; Zhang, M. Review of ecosystem service functional value assessment methods. China Popul. Resour. Environ. 2005, 15, 88-92. [CrossRef]

26. Wang, Y.; Gao, J.X.; Wang, J.S.; Zheng, H. Review on Evaluation method of ecosystem services value. China Popul. Resour. Environ. 2013, 23, 337-339.

27. Zhao, J.L.; Wang, L.X.; Han, H.R.; Kang, F.F.; Zhang, Y.L. Research progress and trend of forest ecosystem service value assessment. Chin. J. Ecol. 2013, 32, 2229-2237. [CrossRef]

28. Xie, G.D.; Zhang, C.X.; Zhang, S.C.; Xiao, Y.; Lu, C.X. The value of ecosystem services in China. Resour. Sci. 2015, 37, 1740-1746.

29. Wang, B.; Lu, S.W. Evaluation of economic forest ecosystem services in China. Chin. J. Appl. Ecol. 2005, 2, 417-425.

30. Lei, J.Y.; Jia, A.P.; Yi, Z.R.; Ji, L.D.; Han, Z.X. The investigation and evaluation of water and fertilizer management of dominant varieties in different wine grape growing districts, Ningxia. Ningxia J. Agric. For. Sci. Technol. 2018, 59, 8-10. [CrossRef]

31. Zhang, Y.H.; Zhang, Y.M. Counterm easures for vinifera industry development in Hongsibu district of Ningxia province. Ningxia J. Agric. For. Sci. Technol. 2016, 57, 15-17. [CrossRef]

32. Yang, R.B.; Gao, H.L. Current situation of development and counterm easures of grape industry in Hongsibu in Ningxia. Ningxia J. Agric. For. Sci. Technol. 2013, 54, 101-102, 107. [CrossRef]

33. Guo, W.H.; Gao, Y. The Variation of Vineyard Net $\mathrm{CO}_{2}$ Exchange under Different Conditions in Northwest Arid. J. Irrig. Drain. 2013, 32, 107-109, 136.

34. Pitacco, A.; Meggio, F. Carbon budget of the vineyard-A new feature of sustainability. In Proceedings of the Paper Presented at the 38th Word Vine and Wine Congress, Mainz, Germany, 5 July 2015; University of Padova: Padova, Italy, 2015.

35. Bao, L.M. Exploration and Practices of Agricultural Water Rights Trading in Hongsibu District of Ningxia. Ningxia J. Agric. For. Sci. Technol. 2017, 58, 46-48.

36. Song, Z.W.; Sun, M.Y.; Yang, R.J.; Dou, G.Y.; Zhang, Y. Evaluation of ecosystem service function of grape industry at the eastern foot of Helan mountain, Ningxia, China. Chin. J. Appl. Ecol. 2019, 30, 979-985. [CrossRef]

37. Liu, K.C.; Su, S.Q.; Jiang, J.F.; Xu, W.A. Preliminary investigation of air anions in different vegetation types. For. Environ. Sci. 2002, 18, 37-39. [CrossRef]

38. Yang, S.Y.; Wu, Q.; Yang, W.; Xia, S.G.; Zhang, C.L.; Yang, P. Generation capacity of air anion in three urban forest community. Urban Environ. Urban Ecol. 2014, 6, 23-27.

39. Ma, X.H.; Sun, G.N.; Ren, Z.Y. The Values of Vegetation Purified Air and Its Measure In Xi'an City. J. Arid. Land Resour. Environ. 2002, 16, 83-86. [CrossRef]

40. Gao, G. Soil and water conservation monitoring and evaluation of yanghuang irrigation project for poverty alleviation in Ningxia. Ningxia J. Agric. For. Sci. Technol. 2011, 52, 53-55, 57. [CrossRef]

41. Wang, R.Q. Monitoring and exploration of soil and water conservation in the yanghuang poverty alleviation project in Ningxia: A case study of Hongsibu irrigated area dominated by wind erosion. Ningxia J. Agric. For. Sci. Technol. 2009, 4, 14-17. [CrossRef]

42. Xiao, H.; Ouyang, Z.Y.; Zhao, J.Z.; Wang, X.K. Forest ecosystem services and their ecological valuation-A case study of tropical forest in Jianfengling of Hainan island. Chin. J. Appl. Ecol. 2000, 11, 481-484. [CrossRef]

43. Wang, Z.L.; Bao, L.; Ge, X.W.; Wang, R.; Sun, Q. Effects of organic fertilization by drip irrigation on soil microbial biomass carbon, nitrogen and enzyme activities in wine vineyards. Soil Fertil. Sci. China 2019, 61-67, 97. [CrossRef]

44. Tian, Z.H.; Wang, Y.N. Eco-Economic Value of Soil Conservation Service of Orchard Ecosystems in Beijing Mountainous Area: A Case Study of Orchard in Pinggu District of Beijing. Sci. Silvae Sin. 2011, 47, 165-171.

45. Li, Z.K.; Zhou, B.B. Preliminary report on forest resources in Beijing. For. Econ. 2001, 2, 36-42.

46. Ma, L.; Wang, Z.L.; Wang, R.; Chang, F.D.; Sun, Q. Accumulation Dynamics and Distribution of Nutrient in Red Globe Grape. Southwest China J. Agric. Sci. 2019, 32, 604-608. [CrossRef]

47. Si, P.; Yu, H.L.; Gao, D.T.; Shao, W.; Qiao, X.S.; Chen, J.R. Effects of intercropping herbages on carbon source metabolism of soil microbial community in sandy vineyard. Agric. Res. Arid Areas 2017, 35, 247-254. [CrossRef]

48. Zhang, W.; Ricketts, T.H.; Kremen, C.; Carney, K.; Swinton, S.M. Ecosystem services and dis-services to agriculture. Ecol. Econ. 2007, 64, 253-260. [CrossRef]

49. Zeng, C.; Wang, L.; Wang, L. The innovative development path of wine tourism industry in the region at the eastern foot of Helan mountain. North. Hortic. 2019, 426, 173-181.

50. Li, Y.; Li, L. Research on wine tourism development in Hongsipu District. North. Hortic. 2016, 10, 170-174. [CrossRef]

51. Vitousek, P.M.; Cassman, K.; Cleveland, C.; Crews, T.; Field, C.B.; Grimm, N.B.; Sprent, J.I. Towards an ecological understanding of biological nitrogen fixation. Biogeochemistry 2002, 57, 1-45. [CrossRef]

52. Paul, E.A.; Clark, F.E. Soil Microbiology and Biochemistry; Academic Press: New York, NY, USA, 1996.

53. Li, D.Q.; Liang, Y.M.; Hou, X.L.; Huang, J.; Jiang, J.; Ruan, C.J.; Hao, D.Y.; Qi, J.Y. A Study on the Functions and Benefits of Seabuckthorn for Improving Eco-environment of the Loess Plateau. Hippophae 2003, 16, 16-21. [CrossRef]

54. Yan, P.H. Planting hippophae rhamnoides L and taking the road of double harvest of ecological and economic benefits. China Water Resour. 2003, 5, 75-76. [CrossRef]

55. Feng, R.; Guo, J.Y.; Ling, X.; Wang, T.S.; Li, J.R. Evaluation of Ecological Benefit of Hippophae rhamnoides Forestry Projects in Wuqi County. Glob. Seabuckthorn Res. Dev. 2009, 7, 25-30. [CrossRef] 
56. Savi, T.; Petruzzellis, F.; Martellos, S.; Stenni, B.; Borgo, A.D.; Zini, L.; Nardini, A. Vineyard water relations in a karstic area: Deep roots and irrigation management. Agric. Ecosyst. Environ. 2018, 263, 53-59. [CrossRef]

57. Eldridge, D.J.; Freudenberger, D. Ecosystem wicks: Woodland trees enhance water infiltration in a fragmented agricultural landscape in eastern Australia. Austral Ecol. 2010, 30, 336-347. [CrossRef]

58. Houlahan, J.E.; Findlay, C.S. Estimating the 'critical' distance at which adjacent land-use degrades wetland water and sediment quality. Landsc. Ecol. 2004, 19, 677-690. [CrossRef]

59. Liang, Z.; Tingting, X.; Feifei, G.; Ruteng, W.; Zhilei, W.; Hua, L.; Hua, W. Carbon Storage Distribution Characteristics of Vineyard Ecosystems in Hongsibu, Ningxia. Plants 2021, 10, 1199. [CrossRef]

60. Rapidel, B.; Ripoche, A.; Allinne, C.; Metay, A.; Deheuvels, O.; Lamanda, N.; Gary, C. Analysis of ecosystem services trade-offs to design agroecosystems with perennial crops. Agron. Sustain. Dev. 2015, 35, 1373-1390. [CrossRef]

61. Xue, T. Research of Free-Buried Mode Based on Biodegradable Liquid Film in Grapevine Soil-Burial Areas; Northwestern A \& F University: Yangling, China, 2018.

62. Unger, P.W.; Vigil, M.F. Cover crop effects on soil water relationships. J. Soil Water Conserv. 1998, 53, $200-207$.

63. Prosdocimi, M.; Jordán, A.; Tarolli, P.; Keesstra, S.; Novara, A.; Cerdà, A. The immediate effectiveness of barley straw mulch in reducing soil erodibility and surface runoff generation in Mediterranean vineyards. Sci. Total Environ. 2016, 547, 323-330. [CrossRef] [PubMed] 